\section{Efficacy of electrolyzed water on reducing some foodborne pathogens in cutting boards}

\section{ABSTRACT}

Cross-contamination is an important source of foodborne pathogens, from cutting boards, knives and food preparation surfaces. Methods for reducing or inactivating pathogens from these sources are necessary for establishing food safety. Electrolyzed water (EW), nowadays is gaining popularity as a sanitizer in the food industry. The aim of this study was to determine the efficacy of EW for reducing or eliminating Salmonella Typhimurium, Escherichia coli, Listeria monocytogenes, and Staphylococcus aureus on unscarred, wooden cutting boards. For this purpose, 1 milliliter of each selected pathogen $\left(10^{9} \mathrm{CFU} / \mathrm{mL}\right)$ was inoculated on a different 100 $\mathrm{cm}^{2}$ (10x10) unscarred cutting board. After the inoculation, the boards were air-dried for the attachment of the pathogens for 1 hour and then each cutting board immersed in $500 \mathrm{ml}$ of EW (5\% concentration) at room temperature for $10 \mathrm{~min}$. After that, the number of the pathogens on cutting boards and also in soaking water was determined by sampling at minutes 0 (zero) and 30 , and hours 2,8 and 24 . Treatment of inoculated cutting boards with EW reduced all the pathogens populations by $1 \log$ $\mathrm{CFU} / 100 \mathrm{~cm}^{2}$ at minute 0 (zero). S. aureus and S. Typhimurium was not detected after the $8^{\text {th }}$ hour, also E. coli and L. monocytogenes were not survived after 2 hours. All of the pathogens were not detected in soaked EW after the treatment. This study presented that immersing cutting boards into EW could be preferred as a useful method for reducing some foodborne pathogens.

Keywords: Cleaning, decontamination, disinfection, electrolyzed water, food safety.

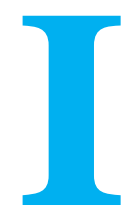

\section{NTRODUCTION}

Cross contamination is commonly implicated as an important factor in the spread of foodborne diseases. Food contact surfaces, like cutting boards or utensils, have been pointed at as a route of cross-contamination, repeatedly. They could serve as a contamination source through transferring the disease agents between foods and the ones that could not be cooked further before eating, they allow bacteria to multiply particularly if raw meat or meat products remains on the surfaces (Kusumaningrum et al., 2003). Effectively sterilizing cutting boards is an important tool that minimizes the cross-contamination risk and resulting foodborne illness. However, cleaning of cutting boards with water and commercial chemical cleaners are not enough for total elimination of bacteria therefore for complete hygiene antimicrobial agents are necessary (Huang et al., 2008).

How to cite this article

İplikçioğlu Çil, G., Cengiz, G., Şireli, T.U. (2020). Efficacy of electrolyzed water on reducing some foodborne pathogens in cutting boards. Journal of Advances in VetBio Science and Techniques. 5(2): 57-63. https://doi.org/10.31797/vetbio.753673
Research Article

Güzin İPLIKKÇİŎLU ÇíL ${ }^{1 \mathrm{a}}$ Görkem CENGİ ${ }^{1 b}$ Ufuk Tansel ŞíRELI $\dot{I}^{1 \mathrm{c}}$

${ }^{1}$ Ankara University, Faculty of Veterinary Medicine, Department of Food Hygiene and Technology, Dışkapı / Ankara / TÜRKIYE

ORCID-

${ }^{\mathrm{a}}$ 0000-0001-6897-8222

b 0000-0001-9853-565X

${ }^{\mathrm{c}}$ 0000-0001-6180-0755

Correspondence Güzin İPLİKÇİOĞLU ÇİL Dr. Öğr. Üyesi iplikcioglu@ veterinary.ankara.edu.tr

Article info

Submission: 16-06-2020

Accepted: 20-08-2020

Online First: 27-08-2020

e-ISSN: 2548-1150 doi prefix: $10.31797 /$ vetbio - http://dergipark.org.tr/vetbio

This work is licensed under a Creative Commons Attribution 4.0 International License (c) (i) 
Cutting boards should be cleaned and sanitized often, thus, they are used repeatedly to prepare food to a large number of people in restaurants and food producing facilities (Monnin et al., 2012). Although there are several commercial products with different properties for this purpose, research is still being conducted into the new ones. Recently in the food industry, electrolyzed water (EW) as a sanitizer, is gaining popularity by reducing or eliminating bacteria on food products, utensils, and non-food contact surfaces (Rahman et al., 2016). EW was first developed in Japan and is reported to have a strong bactericidal effect on most pathogenic bacteria important for food safety (Çil et al., 2012).

EW is produced with an electrolysis chamber which contains a separating membrane between the cathode and anode electrodes by electrolysis of $\mathrm{NaCl}$ solutions. By exposing the electrodes to direct current voltages, different EW solutions are generated at the negative and positive poles. Chloride and hydroxide, the negatively charged ions, in the diluted salt solution move to the anode and give up electrons and become chlorine gas, hypochlorite ion, hypochlorous acid oxygen gas and hydrochloric acid and by this reaction a solution with high ORP and a low $\mathrm{pH}$ is generated, called acidic electrolyzed water (AEW). Meanwhile hydrogen and sodium (positively charged ions) are moving to the cathode and taking up electrons and become sodium hydroxide and hydrogen gas. By this reaction alkaline electrolyzed water (AlEW) with a high $\mathrm{pH}$ and a low ORP is generated (Wang et al., 2019; Athayde et al., 2018). The presence of chlorine and a high ORP are accepted as the main antimicrobial activity of AEW. Moreover, with the development of this mechanism, a third type of electrolyzed water was produced. By using a single cell chamber without the separating membrane, Neutral EW (NEW) partially mixed with hydroxide ions, which has an ORP of $750-900 \mathrm{mV}$ a neutral $\mathrm{pH}$ is produced from the anode. Because of its neutral $\mathrm{pH}$, in comparison with $\mathrm{AEW}$, it is believed to be NEW is less corrosive for processing equipment (Ding and Liao, 2019; Subrato et al., 2012).

Safety is the main advantage of EW. EW is different from many disinfectants it is not corrosive for tissues. Because no hazardous chemicals added during the production, it has less adverse impact on the environment and it becomes ordinary water again, by the contact with organic matter or when diluted by tap water or reverse osmosis. Additionally, EW has very little side effects, is relatively cheaper than other sanitizers, it is easy to process, and microorganisms do not acquire resistance. (AlHoly and Rasco, 2015; Xuan and Ling, 2019). The only disadvantage of this sanitizer is its effectiveness is reduced by the presence of organic matters and with time, the bactericidal activity of EW is reduced due to chlorine loss (Ogunniyi et al., 2019).

The study was designed to determine the efficacy of EW for reducing or killing Escherichia coli, Salmonella Typhimurium, Listeria monocytogenes, and Staphylococcus aureus on cutting boards and compare its stability over time.

\section{MATERIALS and METHODS}

\section{Bacterial cultures and inoculum preparation}

Common foodborne pathogens chosen for the experiment. E. coli NCTC 12900, Salmonella Typhimurium ATCC 14028, Listeria monocytogenes ATCC 7646 and Staphylococcus aureus ATCC 25923 strains were individually cultured and activated by inoculating cultures to the specific mediums. Pathogens were maintained in $10 \mathrm{ml}$ of Brain Heart Infusion Broth (Oxoid CM1135) at $37^{\circ} \mathrm{C}$ by daily transfer. With a spectrophotometer (Thermo Scientific, TM1000) bacterial 
concentrations were measured by the absorbance of the bacterial suspension at 600 $\mathrm{nm}$. All strains are adjusted to a cell count of $10^{9} \mathrm{CFU} / \mathrm{mL}$ before the experiment.

\section{Electrolyzed water preparation}

A commercial electrolyzed water sanitizer used for the experiment. Electrolyzed water with a concentration of $5 \%$ were prepared in accordance with the manufacturers recommendation by using the stock. Final EW treatment solutions have characteristic odor, they are colorless, $\mathrm{pH}$ range of 6.9-7.0 and ORP 720-750.

\section{Cutting board preparation and sample inoculation}

To determine the antibacterial activity, cutting boards which are new (unscarred), hardwood, and $10 \times 10 \mathrm{~cm}^{2}$ size were used in the study. Each board was sterilized in the autoclave at $121{ }^{\circ} \mathrm{C}$ for $20 \mathrm{~min}$ (wrapped with an aluminium foil). A volume of 1 millilitre of each bacterial culture of selected pathogen $\left(10^{9} \mathrm{CFU} / \mathrm{ml}\right)$ was inoculated on a different cutting board and spread evenly on $100 \mathrm{~cm}^{2}$ at room temperature $\left(22-23{ }^{\circ} \mathrm{C}\right)$. After the inoculation, they were left to dry in a laminar flow cabinet under aseptic conditions for 1 hour at room temperature for the attachment of the strains.

\section{Sanitization treatment}

Following the attachment, each cutting board immersed in $500 \mathrm{ml}$ of EW treatment solution at room temperature for $10 \mathrm{~min}$. After the treatment, the surviving population of the pathogens on cutting boards and in soaking solution was determined by sampling at minutes 0 and 30, and hours 2, 8 and 24. One cutting board which is inoculated but not immersed to the EW was evaluated as a control group for each pathogen to control the efficiency of inoculation. After immersion, by using a sterile tong each cutting board was aseptically removed and water was drained from the board (Venkitanarayanan et., 1999).

\section{Microbiological analysis}

Two sterile cotton swabs was used to swab the $100 \mathrm{~cm}^{2}$ surface area of each treated cutting board and the control group boards, from right to left and from top to bottom. The swabs were transferred in a $9 \mathrm{ml}$ sterile peptone water. One milliliter from this water was then serially diluted with $9 \mathrm{ml}$ of sterile peptone water and $0,1 \mathrm{ml}$ from each dilution plated onto specific mediums for pathogens. As specific mediums, Brilliant-Green Phenol-Red Lactose Sucrose Agar (Merck 107237) for S. Typhimurium, Baird Parker (Oxoid CM1127) for S. aureus, Oxford Agar Base (Merck, 107004) for $L$. monocytogenes and Violet Red Bile Lactose Agar (Oxoid CM0968) for E. coli were used. All plates were incubated at $37^{\circ} \mathrm{C}$ for $24-36 \mathrm{~h}$ and counted. Also, $1 \mathrm{ml}$ of the treatment water was transferred to $9 \mathrm{ml}$ sterile peptone water and enumerated likewise.

\section{RESULTS}

According to the control groups, E. coli, S. Typhimurium and $S$. aureus were attached $10^{6}$ $\mathrm{CFU} / \mathrm{cm}^{2}$, and L. monocytogenes was attached $10^{5} \mathrm{CFU} / \mathrm{cm}^{2}$ on to the cutting boards. Compared to the control groups, immersion to the electrolyzed water, caused $1 \log$ decrease in all pathogens at minute 0 . L. monocytogenes and $E$. coli counts were determined below the detection limit at the end of the $2^{\text {nd }}$ hour and $S$. Typhimurium and $S$. aureus at the end of the $8^{\text {th }}$ hour (Table 1). Further, none of the pathogens were detected in the soaked water samples. 
Table 1. Attachment of the control groups and reduction of pathogens after the EW treatments.

\begin{tabular}{|c|c|c|c|c|}
\hline & & ing Board & $\left.\mathrm{FU} / 100 \mathrm{~cm}^{2}\right)$ & \\
\hline & S. Typhimurium & S. aureus & L. monocytogenes & E. coli \\
\hline Control & $10^{6}$ & $10^{6}$ & $10^{5}$ & $10^{6}$ \\
\hline $23^{\circ} \mathrm{C} 0$ min & $10^{5}$ & $10^{5}$ & $10^{4}$ & $10^{5}$ \\
\hline $23^{\circ} \mathrm{C} 30 \mathrm{~min}$ & $10^{5}$ & $10^{5}$ & $10^{4}$ & $10^{5}$ \\
\hline $23^{\circ} \mathrm{C} 2 \mathrm{hr}$ & $10^{4}$ & $10^{5}$ & $<200$ & $<200$ \\
\hline $23^{\circ} \mathrm{C} 8 \mathrm{hr}$ & $<200$ & $<200$ & $<200$ & $<200$ \\
\hline $23^{\circ} \mathrm{C} 24 \mathrm{hr}$ & $<200$ & $<200$ & $<200$ & $<200$ \\
\hline
\end{tabular}

\section{DISCUSSION}

Various sanitizers are used to reduce microbial loads on cutting boards surfaces; nevertheless, different factors may restrict their applications. Concentration, contact time, active ingredients, residual effect, formation of toxic by-products, effectiveness in the presence of organic matter are among these factors (Al-Qadiri et al., 2016). In our study we search the efficacy of a promising sanitizer, electrolyzed water, on to the common foodborne pathogens, on cutting boards. Our results showed that, immersing the contaminated cutting boards into the electrolyzed water easily eliminated the selected pathogens. At the end of the 8th hour, all of the pathogens were under the detection limits, when compared with the control groups. With the results of control groups, our study, also has highlighted the fact that pathogens may remain viable on cutting board surfaces and may recontaminate other foods.

Electrolyzed water has become an effective sanitizer in food industry. In a meta-analysis of Afari and Hung (2018), developed for an overall estimation of the pathogen reductions achievement after the EW treatment of food products, results showed that when compared with the other control group sanitizers, EW was more effective in reducing pathogens on foods. The efficacy of electrolyzed water in reducing microbial population has also been reported by other researchers. Venkitanarayanan et al. (1999) similarly indicated a higher bacterial reduction, 5 to $6 \log \mathrm{CFU} / \mathrm{ml}$, in their study. They search the effectiveness of acidic electrolyzed water on E. coli $\mathrm{O} 157: \mathrm{H} 7$ and $L$. monocytogenes on cutting board surfaces by immersion. They preferred to use smooth, plastic cutting boards and compare their results with deionized water. The reduction was determined as only 1 to $1.5 \log \mathrm{CFU} / \mathrm{ml}$ in deionized water. Likewise, they enumerate the treatment waters. They reported that, no E. coli O157:H7 and L. monocytogenes were detected in EW used for the soaking cutting boards, whereas the pathogens were survived in the deionized water. In another study, it was investigated the efficacy of neutral electrolyzed water to reduce populations of $E$. coli, Pseudomonas aeruginosa, S. aureus, and $L$. monocytogenes on pine-wood cutting boards. As a result, $4 \log \mathrm{CFU} / 50 \mathrm{~cm}^{2}$ reduction was determined in all pathogens with soaking the cutting boards into the EW solutions for 5 minutes. In the same study, no survivors were detected in washing solutions after the treatment with NEW while, in control washing solution, an average of $6 \mathrm{log} \mathrm{CFU} / \mathrm{ml}$ of all strains was recovered (Deza et al., 2007). Monnin et al. (2012) inoculated the cutting boards made of hardwood and bamboo with $E$. 
coli $\mathrm{K} 12$ and L. innocua and washed them with neutral electrolyzed water. After the washing protocol, they found a 3 to $4 \log$ CFU/100 $\mathrm{cm}^{2}$ reduction in both microorganisms. Their findings are slightly low, when compared with previous studies results. The key difference in their methodology is, they scarred the cutting boards used in the experiment, with a serrated kitchen knife in order to simulate normal usage. It is known that, cutting boards are often scarred by knife edges over time and these scarred parts can protect bacteria from cleaning and sanitation. Same state is supported in the studies of Kusumaningrum et al. (2002) and Lee et al. (2007). Unlike, in the study of Al-Qadiri et al. (2016), they also used maple-hard wood cutting-boards scarred with a pizza-knife, to determine the reduction effect of electrolyzed water on S. Typhimurium, E. coli O157:H7, C. jejuni, L. monocytogenes and S. aureus. After 5 min of treatment, 4 and $5 \log$ reductions were achieved for Gram-negative and Gram-positive strains, respectively. Fabrizo and Cutter (2003) demonstrated in their study, quite high reduction levels (> 8 log) after the EW treatment of the $S$. Typhimurium and $L$. monocytogenes. But they did their experiment on only cell suspensions. It is important to simulate the kitchen conditions in order to obtain rational results and determine the real efficacy of the disinfectant.

Another fact in different studies is the type of cutting board material used in the experiment. Plastic boards are considered easier to sanitize than wooden ones. Beside certain wood species have endogenous antibacterial properties, by their physical structure, wood is able to absorb moisture and protect bacteria from cleaning and sanitizing. Also, studies revealing that wooden boards could absorb bacterial suspension and the inner part of the wood might still remain wet and retain most of the bacteria while the surface appeared dry. Deza et al. (2007), evaluated the effectiveness of neutral electrolyzed water on E. coli,
Pseudomonas aeruginosa, S. aureus, and $L$. monocytogenes, on plastic and wooden kitchen cutting boards and reported a significant difference between the materials used. In plastic boards the reduction of bacterial populations was $5 \log \mathrm{CFU} / 50 \mathrm{~cm}^{2}$, whereas in wooden cutting boards it was $3 \log \mathrm{CFU} / 50$ $\mathrm{cm}^{2}$. Monin et al. (2012) compared two cutting board material types, bamboo and hardwood, for the residual bacterial numbers on their surfaces following the sanitation with electrolyzed water. Researchers choose bamboo for the study due to its increasing popularity as a sustainable, environmentally-friendly alternative to other materials, like wood or plastic. They reported no significant differences in surviving bacteria counts between hard-wood and bamboo material. Chiu et al. (2006) studied the efficacy of EW treatment in inactivating V. parahaemolyticus on the surfaces of different cutting boards made from bamboo, wood and plastic). Soaking the cutting boards in EW for 5 min eliminated the $V$. parahaemolyticus on both plastic and wood boards. However, the EOW treatment resulted ineffective on the bamboo boards. Al-Qadiri et al. (2016) stated in their study, longer exposure times for NEW were required for the effectiveness against microbial contamination on wooden compared to polypropylene surfaces. In a study of Jeon et al. (2018), the reduction effect of various sanitizers on L. innocua biofilm cells on rubber, polypropylene, glass and stainless-steel surfaces was searched. They reported as, washing contact surfaces with $30,50,70$, and $120 \mathrm{ppm}$ of AEW reduced the population of L. innocua biofilm cells significantly and among the fourfood contact surfaces the most effective biofilm reduction was obtained on polypropylene.

\section{CONCLUSIONS}

This study showed that, EW could be used as a chemical to sanitize the wooden cutting boards. Besides, research need to compare its effectiveness with the common disinfectants 
used in the food industry. Further studies should be conducted to determine the effect of electrolyzed water on the presence of organic matter. As a result of all these studies, it will be possible to determine the most appropriate and economical use of EW

\section{ACKNOWLEDGMENTS}

This study was presented at the $4^{\text {th }}$ International VETIstanbul Group Congress, Almaty

Kazakhstan.

\section{REFERENCES}

Afari, G. K., Hung, Y. C. (2018). A meta-analysis on the effectiveness of electrolyzed water treatments in reducing foodborne pathogens on different foods. Food Control, 93, 150-164. doi:10.1016/j.foodcont.2018.06.009.

Al-Holy, M. A., Rasco, B. A. (2015). The bactericidal activity of acidic electrolyzed oxidizing water against Escherichia coli O157: H7, Salmonella Typhimurium, and Listeria monocytogenes on raw fish, chicken and beef surfaces. Food Control, 54, 317-321. doi:10.1016/j.foodcont.2015.02.017.

Al- Qadiri, H. M., Ovissipour, M., Al- Alami, N., Govindan, B. N., Shiroodi, S. G., Rasco, B. (2016). Efficacy of neutral electrolyzed water, quaternary ammonium and lactic acid-based solutions in controlling microbial contamination of food cutting boards using a manual spraying technique. Journal of Food Science, 81(5), 1177-1183. doi:10.1111/17503841.13275.

Athayde, D. R., Flores, D. R. M., Silva, J. S., Silva, M. S., Genro, A. L. G., Wagner, R., Cichoski, A. J. (2018). Characteristics and use of electrolyzed water in food industries. International Food Research Journal, 25(1), 11-16.

Chiu, T. H., Duan, J., Liu, C., Su, Y. C. (2006). Efficacy of electrolysed oxidizing water in inactivating Vibrio parahaemolyticus on kitchen cutting boards and food contact surfaces. Letters in Applied Microbiology, 43(6), 666-672. doi:10.1111/j.1472-765X.2006.02006.x.

Çil, G. İ., Demirel, Y. N., Şireli, U. T. (2012). Elektrolize su kullanilarak tavuk etinde $\mathrm{S}$. Typhimurium'un inaktivasyonu. Veteriner Hekimler Derneği Dergisi, 83(2), 48-53.

Deza, M. A., Araujo, M., Garrido, M. J. (2007). Efficacy of neutral electrolyzed water to inactivate Escherichia coli, Listeria monocytogenes, Pseudomonas aeruginosa, and Staphylococcus aureus on plastic and wooden kitchen cutting boards. Journal of Food Protection, 70(1), 102-108. doi:10.4315/0362-028X-70.1.102.

Ding, T., Liao, X. (2019). Decontamination efficacy and principles of electrolyzed water. In: Ding T., Oh DH, Liu D. (ed's), Electrolyzed water in food: fundamentals and applications. Singapore, Springer, 17-30.

Fabrizio, K. A., Cutter, C. N. (2003). Stability of electrolyzed oxidizing water and its efficacy against cell suspensions of Salmonella Typhimurium and Listeria monocytogenes. Journal of Food Protection, 66(8), 1379-1384. doi:10.4315/0362-028X-66.8.1379.

Huang, Y. R., Hung, Y. C., Hsu, S. Y., Huang, Y. W., Hwang, D. F. (2008). Application of electrolyzed water in the food industry. Food Control, 19(4), 329345. doi:10.1016/j.foodcont.2007.08.012.

Jeon, H. R., Kwon, M. J., Yoon, K. S. (2018). Control of Listeria innocua biofilms on food contact surfaces with slightly acidic electrolyzed water and the risk of biofilm cells transfer to duck meat. Journal of Food Protection, 81(4), 582-592. doi: 10.4315/0362028X.JFP-17-373.

Kusumaningrum, H. D., Riboldi, G., Hazeleger, W. C., Beumer, R. R. (2003). Survival of foodborne pathogens on stainless steel surfaces and crosscontamination to foods. International Journal of Food Microbiology, 85(3), 227-236. doi:10.1016/S01681605(02)00540-8.

Kusumaningrum, H.D., van Putten, M.M., Rombouts, F.M., Beumer, R.R. (2002). Effects of antibacterial dishwashing liquid on foodborne pathogens and competitive microorganisms in kitchen sponges. Journal of Food Engineering, 65, 61-65. doi:10.4315/0362-028X-65.1.61.

Lee, J., Cartwright, R., Grueser, T., Pascall, M.A. (2007). Efficiency of manual dishwashing conditions on bacterial survival on eating utensils. Journal of Food Engineering, 80, 885-891. doi:10.1016/j.jfoodeng.2006.08.003.

Monnin, A., Lee, J., Pascall, M. A. (2012). Efficacy of neutral electrolyzed water for sanitization of cutting boards used in the preparation of foods. Journal of Food Engineering, 110(4), 541-546. doi:10.1016/j.jfoodeng.2011.12.039.

Ogunniyi, A. D., Dandie, C. E., Ferro, S., Hall, B., Drigo, B., Brunetti, G., Lombi, E. (2019). Comparative antibacterial activities of neutral electrolyzed oxidizing water and other chlorine-based sanitizers. Scientific Reports, 9(1), 1-13. doi:10.1038/s41598-019-56248-7.

Rahman, S. M. E., Khan, I., Oh, D. H. (2016). Electrolyzed water as a novel sanitizer in the food industry: current trends and future perspectives. Comprehensive Reviews in Food Science and Food Safety, 15(3), 471-490. doi:10.1111/15414337.12200. 
Subrota, H., Surajit, M., PS, M., Shilpa, V., Yogesh, K., Dipika, Y. (2012). Electrolyzed oxidized water (EOW): non-thermal approach for decontamination of food borne microorganisms in food industry. Food and Nutrition Sciences, 3(6), 1-9. doi:10.4236/fns.2012.36102.

Venkitanarayanan, K. S., Ezeike, G. O., Hung, Y. C., Doyle, M. P. (1999). Inactivation of Escherichia coli O157: H7 and Listeria monocytogenes on plastic kitchen cutting boards by electrolyzed oxidizing water. Journal of Food Protection, 62(8), 857-860. doi:10.4315/0362-028X-62.8.857.

Wang, H., Duan, D., Wu, Z., Xue, S., Xu, X., Zhou, G. (2019). Primary concerns regarding the application of electrolyzed water in the meat industry. Food Control, 95, 50-56. doi:10.1016/j.foodcont.2018.07.049.

Xuan, X., Ling, J. (2019). Generation of electrolyzed water. In: Ding T., Oh DH, Liu D. (ed's), Electrolyzed water in food: fundamentals and applications. Singapore, Springer, 1-17. 